\title{
Law Enforcement Problems at the Appointment of Administrative Punishment
}

\author{
Natalia V. Fedorenko ${ }^{1}$, Veronika V. Kolesnik ${ }^{2}$, Julia V. Fedorenko ${ }^{3}$
}

\begin{abstract}
:
The present article is designed to draw the attention of readers to the existing problems in law-enforcement activity at the purpose of administrative punishments. In the article the problems of the general and private character which are not known have been analyzed. The attention is focused on an imperfect legislative regulation which, according to authors, is the cornerstone of many problems in law enforcement.
\end{abstract}

Authors consider the problems of interpretation of the concept "administrative punishment" and the questions of the creation of an optimum system of punishments, as prescribed by the administrative law, a prerequisite of a corruption. The provisions of the Code of the Russian Federation on Administrative Offences provide the choice of a look and the degree of severity of administrative punishments for offenses.

As a result, authors formulate conclusions about existence in activity to destination of administrative punishments of essential quantity of unresolved problems, both in a system, and in a private character. Besides corruption provisions of the administrative law, according to authors, act as initial prerequisites of key problems of law enforcement.

Keywords: Administrative punishment, law enforcement problems, system of administrative punishments, corruption, dispositivity.

\footnotetext{
${ }^{1}$ Corresponding author, Doctor of Sciences, Candidate of Law Sciences, Department of Civil Procedure, Rostov State University of Economics, Rostov-on-Don.

${ }^{2}$ Candidate of Law Sciences, Senior lecturer of Civil Procedure, Rostov State University of Economics, Rostov-on-Don.

${ }^{3}$ Candidate of Law Sciences, Associate professor of Civil Procedure, Rostov State University of Economics, Rostov-on-Don.
} 


\section{Introduction}

Activity to destination of administrative punishments, as well as any other lawenforcement activity may contain certain flows. On the one hand, shortcomings of law enforcement can be caused by an imperfect legislative regulation, with another, the most deformed practice of law enforcement. However more often problems have complex character and are determined by $\alpha$ significant number of factors.

Social, economic, personal, political, ideological and many other reasons and conditions can be their cornerstones. The list of similar problems is quite extensive and doesn't move to calculation as one solved problem leads to a chain of other not resolved questions. For example, with the adoption of the resolution of the Plenum of the Supreme Arbitration Court of the Russian Federation of 11.07.14 No. $47^{4}$ many problems connected with administrative prosecution for violations of the "alcoholic" legislation ${ }^{5}$ have received the decision, however it, in turn, hasn't led to full elimination of contradictions.

\section{Literature review}

It must be kept in mind that problems of law enforcement can't exist in separation of the theory and practice, formulated from the scientific developments and the legislative initiatives of various authors. In essence, the theory is designed to provide practice with new original decisions and practice the theory when the problems are demanding answers. The proceeding from it, with the consideration of problems of law enforcement at the purpose of administrative punishments and the theoretical aspect, is anyway affected.

Authors such as A.B. Agapov, T.Yu. Kourova investigating problems of administrative responsibility, others as L.L. Popov, N.Yu. Hamaneva raising the general questions of administrative punishments have considerably promoted research on problems in this sphere.

Besides L.B. Antonova, A.S. Dugenets, A.N. Derygi have essentially affected the level of study of a problem of purpose of administrative punishment of work as well as Sackcloth and many others.

\footnotetext{
${ }^{4}$ The resolution of the Plenum of the Supreme Court of Arbitration of the Russian Federation of July 11, 2014 No. 47 "About some questions of practice of application by arbitration courts of the Federal law "About State Regulation of Production and Turnover of Ethyl Alcohol, Alcoholic and Alcohol-containing Products and about Restriction of Consumption (Drinking) of Alcoholic Products"'"//Access from Union of Right Forces ConsultantPlus.

${ }^{5}$ See about it: Yachmenyov G. G. The comment to the resolution of the Plenum of the Supreme Arbitration Court of the Russian Federation of 11.07.14 No. 47 // Arbitration disputes. 2014. No. 4. Page 117-148; Yachmenyov G. G. About some controversial issues of qualification of administrative offenses in the field of turnover of alcoholic products // Arbitration disputes. 2015. No. 4. Page 25.
} 


\section{Methods of conducting research}

General scientific and private science as well as special methods of scientific knowledge have acted as the main methods of a research of problems of law enforcement for administrative punishments. It is possible to allocate such methods as the analysis, the synthesis, the induction, the deduction and as the comparative, the legal, the historical and finally the method of system analysis.

\section{Results}

Thereby, in our opinion, the system of problems in the explored sphere can be divided into several groups: first, it is the law enforcement problems proceeding directly from the text of the legislation of both administrative side and defects in the law; secondly, it is the law enforcement problems caused by the wrong practice of application (interpretation) of the law; thirdly, the problems based on a contradiction of the law and practice of its application; fourthly, theoretical problems of purpose of administrative punishments, influencing lawmaking and law enforcement in this sphere, etc.

As it is possible to notice, each group of the called problems relates to the legislation. Laws define how development of practical activities can serve as an obstacle for their successful implementation. It is recognized from the fact that law enforcement and the application of provisions of the law cannot exist in principle without the rule of the law. Thereby, the key place in the system of problems of law enforcement at the purpose of administrative punishments is possible to create imperfection of the administrative legislation. The last, in turn, generates also contradictions at the realization of the appropriate authority by public authorities and officials, and at the meanwhile discrepancies "as it is necessary" (instructions according to a law letter) and that "as actually" (established practices of purpose of administrative punishments), and many other difficulties.

In our opinion, in this case the thesis is fair: "you want to find problems in the legislation addressing law-enforcement activity and if they need to find the solution, then change the law". At the first approach, this formulation will seem extremely obvious and simple. However, here is necessary to consider that, in fact, we put the sign of identity between the law and the problem of law enforcement. It is valid just in that part where there are gaps, collisions and deficiencies of the law.

The legislation regulating the purpose of administrative punishments is mainly submitted by the Russian Federation Code of Administrative Offences (further - the Code of the Russian Federation on Administrative Offences). This law, as we know, represents the two-uniform systems of substantive and procedural administrative law containing also the system of offenses for which it comes administrative responsibility, and procedural provisions defining an order and a form of response to offenses and attraction to the corresponding responsibility. The Code of the Russian 
Federation on Administrative Offences is also that regulatory legal act which defines, not only an order of purpose of administrative punishments, but also their types, purposes and companion problems. It carries both the general (system), and the private character.

Speaking about problems of the general character, it is necessary to pay attention to that part of the shortcomings of the Code of the Russian Federation on Administrative Offences which belongs to all types of administrative punishments and to all orders of their appointment without exception. The first that gets to the interest of research, is the legislative formulation of the concept "administrative punishment" which according to Art. 3.1 of the Code of the Russian Federation on Administrative Offences. It is defined as the measure of responsibility for the commission of administrative offense established by the state and is applied for the prevention of the commission of new offenses by both the offender, and other persons.

Some disagreement uses the definition of the purpose of administrative punishment in the form of prevention of commission of new offenses. In our opinion, the logic of the creation of the definition isn't right. The legislator shouldn't use the definition to mention the purpose of the administrative punishment as, first, similar inclusion breaks sense of the concept into two untied parts (at first it is about a responsibility measure, the word form about the application purpose without the corresponding sheaf is used later), secondly, the instruction as the purpose - prevention of offenses which isn't the only purpose of administrative punishments.

Though according to some authors, the purpose of punishment is nothing else than the prevention of the new acts doing harm to fellow citizens and in deduction of others from similar actions ${ }^{6}$.

\section{Discussion}

Authors such as L.L. Popov ${ }^{7}$, N.Yu. Hamaneva ${ }^{8}$, A.B. Agapov ${ }^{9}$ and others adhere to the definition provided by the administrative law. There are also positions partially other than legislative. N.M. Konin noted that it is necessary to understand the administrative punishment as "... the administrative measures of responsibility established by the state applied to the guilty legal entities and individuals who have

\footnotetext{
${ }^{6}$ Bekkaria, Ch.O crimes and punishments. Moscow, 1995. Page 105-106.

${ }^{7}$ Administrative law of Russia: textbook / edition L.L. Popov. Moscow: Avenue, 2010. Page 417.

${ }^{8}$ Administrative law of the Russian Federation / under the editorship of N.Yu. Hamaneva. Moscow: Lawyer, 2011. Page 319.

${ }^{9}$ Agapov A.B. Administrative responsibility: textbook. Moscow: Eksmo, 2015. Page 48.
} 
committed these offenses for prevention of commission of new offenses" ${ }^{10}$. As it is possible to notice, this author also left the only purpose - prevention of offenses what we don't agree with. Such representatives of administrative law as M.B. Smolensky and E.V. Drigola speak about a measure of the responsibility applied in the order established by the law to the person who has committed administrative offense $^{11}$. We accept such an option considering that the impossibility of the transfer of all is more than an administrative punishment.

Another problem of general sense affecting the practice of law enforcement at the purpose of administrative punishments is the system of administrative punishments and the logic of its construction and optimization. Speaking about the need of revision of the administrative punishments and the problems of its optimization we accept the opinions of other scholar such as A.S. Dugenets who specified that "the major problem of the system of administrative punishments existing now in the Russian Federation is the solution of questions of its optimization"12. Permission on the question of formation of a uniform rather than a complex system of administrative punishments carries the defining value for the application as a set of punishments and a possibility of a choice to build the correct law enforcement. Not for nothing the system of administrative punishments is recognized as internally organized as a unity consisting of hierarchically ordered set of rather independent types of administrative punishments which set a functional mission of administrative punishment in the social environment ${ }^{13}$.

Smooth functioning of this system will be possible depending on the situation. The hierarchy of punishments for which an increase in functionality plays a crucial role it is necessary to give the harmonious and uniform type to create the accurate system of administrative punishments the general rules of understanding and the best application of available types of punishments ${ }^{14}$.

According to A.S. Mikhlin, the value of the system of punishments is very important for ensuring justice of punishment as depends on the weight of an act punishment that will be chosen. In this respect we have a bit different position ${ }^{15}$. Justification of

\footnotetext{
${ }^{10}$ Kourova T.Yu. Administrative responsibility as one of types of legal responsibility // Modern scientific research and innovations. 2014. No. 9-2 (41). Page 24.

${ }^{11}$ Smolensk M.B., Drigola E.V. Administrative law: textbook. Moscow: KNORUS, 2010. Page 397.

${ }^{12}$ Dugenets A.S. Optimization of system of administrative punishments // Administrative law and process. 2007. No. 3. Page 8-13.

${ }^{13}$ Maximov I.V. The system of administrative punishments by the legislation of the Russian Federation: Monograph. Saratov: SGAP, 2004. Page 18.

${ }^{14}$ Dugenets A.S. Optimization of system of administrative punishments // Administrative law and process. 2007. No. 3. Page 8-13.

${ }^{15}$ Mikhlin A.S. Problems of improvement of system of punishments in the Soviet criminal law // Current problems of criminal law: Collection of scientific works. Moscow: IGP Academy of Sciences of the USSR, 1988. Page 103.
} 
our point of view is built in other aspect. In the category of problems of private character where their distribution is limited to any punishment or a certain administrative offense, etc. For example, problems of purpose of administrative punishment concerning minors ${ }^{16}$, problems of purpose of administrative punishment in the form of deprivation of the special right ${ }^{17}$, etc.

We will adduce arguments in favor of the fact that not always a possibility of the choice of punishments is a positive phenomenon. As an example we will take p.1 Art. 7.27 of the Code of the Russian Federation on Administrative Offences - petty theft in which as the sanction the possibility of the choice or an administrative penalty to the fivefold cost of the stolen property, or administrative detention for a period of up to 15 days, or obligatory works for a period of up to 50 hours is specified. Similar running start for decision-making is a source of the raised discretion which allows to manipulate several decisions depending about law enforcement.

First, the law enforcement official, in this case the judge, can appoint even in identical cases for choice one of three types of administrative punishments in spite of the fact that degree of severity of each of them is different, secondly, the law enforcement official can appoint concerning each of these types of punishments even in similar affairs various sum (the penalty can vary from 1 thousand rubles to the fivefold cost of the kidnapped person of property), various terms (in arrest it can be from one days to 15 days), various duration of punishment (at making decision on appointment as punishment of obligatory works their duration can begin of one hour to fifty hours).

A similar design is very risky as the choice of the decision is left on a payoff to the law enforcement official. Such provisions are called dispositive, allowing wide limits for a discretion. And the dispositivity can act as the basis for the corruption of risks, that is risks of use of powers, in our example the choice of the decision, for corruption and dangerous acts ${ }^{18}$. Such corruption provisions connected with the purpose of administrative punishments in the Code of the Russian Federation on Administrative Offences are quite enough. According to L.B. Antonova "... in the legislation of our country on administrative responsibility establishment of different types of punishments and the minimum and maximum limits in which these sentences can be imposed is widely used. Theoretically such model is justified, however in real

\footnotetext{
${ }^{16}$ Deryga A.N. Problems of law enforcement of the material standards of the Code of the Russian Federation on Administrative Offences directed to protection of the rights of minors // the Modern right. 2009. No. 9. Page 109-112.

${ }^{17}$ Askerov M. Problems of purpose of administrative punishment in the form of deprivation of the special right // Business in the law. Economical and legal magazine. 2012. No. 3. Page 143-145.

${ }^{18}$ See about it, for example: Afanasyev A.Yu. Corruption risks of the law of evidence in criminal trial (pre-judicial production): thesis of Candidate of Law Sciences. Nizhny Novgorod, 2016. Page 54-89.
} 
life it attracts a set of negative consequences, beginning from dissatisfaction of a law-abiding part of society and finishing with existence of the environment for corruption manifestations ${ }^{\prime 19}$.

Similar dispositive provisions exist, for example, in Art. 12.7, 14.16, 18.9 of the Code of the Russian Federation on Administrative Offences and in many others. In fact, each article of the Code of the Russian Federation on Administrative Offences provides administrative responsibility for offenses and sanctions are constructed on every type. In our opinion, similar designs can serve as the base for corruption act. It is simple to be convinced having addressed practice of purpose of administrative punishments when for similar acts different sentences are imposed. Certainly, the choice is influenced by several factors (the identity of the violator, frequency, etc.).

However, if under the same conditions one administrative penalty in the form of the single sum of the stolen property is chosen, and another - administrative detention for a period of 15 days should think about not only the validity of such a decision, but also the interest of the law enforcement official regarding the particular case.

\section{Conclusions}

Obviously, it is not the only problem of the general and private character in lawenforcement activity at the purpose of administrative punishments. In the existing administrative legislation, a set and other unresolved questions have been arisen. In this article we have tried to analyze a very small part of the existing problems. However, in our opinion, the topic is of high importance and it must be improved as soon as possible. The problem of the existence of corruption provisions in the administrative law essentially can affect the quality of the law enforcement at the purpose of the administrative punishments. In this regard their elimination becomes extremely necessary and relevant.

\section{References:}

Afanasyev, A.Yu. 2016. Corruption risks of the law of evidence in criminal trial. Thesis of Candidate of Law Sciences, Nizhny Novgorod.

Agapov A.B. 2015. Administrative responsibility: Textbook. Moscow, Eksmo.

Antonova, L.B. 2015. Problems of purpose of administrative punishments. Bulletin of the Voronezh institute of the Ministry of Internal Affairs of the Russian Federation, No. 2.

Askerov, M. 2012. Problems of purpose of administrative punishment in the form of deprivation of the special right. Business in the law. Economical and legal magazine, No. 3.

Bekkaria, Ch. 1995. About crimes and punishments. Moscow.

\footnotetext{
${ }^{19}$ Antonova L.B. Problems of purpose of administrative punishments // Bulletin of the Voronezh institute of the Ministry of Internal Affairs of the Russian Federation. 2015. No. 2. Page 75-76.
} 
Deryga, A.N. 2009. Problems of law enforcement of the material standards of the Code of the Russian Federation on Administrative Offences directed to protection of the rights of minors. The Modern right, No. 9.

Dugenets, A.S. 2007. Optimization of system of administrative punishments. Administrative law and process, No. 3.

Hamaneva, Yu.N. 2011. Administrative law of the Russian Federation. Moscow, Lawyer.

Kourova, T.Yu. 2014. Administrative responsibility as one of types of legal responsibility. Modern scientific research and innovations, No. 9-2 (41).

Mikhlin, A.S. 1988. Problems of improvement of system of punishments in the Soviet criminal law. Current problems of criminal law: Collection of scientific works. Moscow, IGP Academy of Sciences of the USSR.

Maximov, I.V. 2004. The system of administrative punishments by the legislation of the Russian Federation: Monograph. Saratov, SGAP.

Popov, L.L. 2010. Administrative law of Russia: Textbook. Moscow.

Smolensk, M.B., Drigola, E.V. 2010. Administrative law: Textbook. KNORUS.

Yachmenyov, G.G. 2014. The comment to the resolution of the Plenum of the Supreme Arbitration Court of the Russian Federation of 11.07.14 No. 47. Arbitration disputes, No. 4.

Yachmenyov, G.G. 2015. About some controversial issues of qualification of administrative offenses in the field of turnover of alcoholic products. Arbitration disputes, No. 4. 